\title{
ANTI-ALLERGY POTENTIAL OF PETIS EXTRACT ON IMMUNOGLOBULIN E PRODUCTION BY U266 CELLS
}

\section{(Potensi Anti-alergi Ekstrak Petis terhadap Produksi Imunoglobulin E oleh Sel U266)}

\author{
Rosalind Vivia Tansy ${ }^{1)}$, Agus Budiawan Naro Putra ${ }^{1 *}$, Takuya Sugahara ${ }^{2)}$ \\ ${ }^{1}$ Department of Food Science, School of Life Sciences, Indonesia International Institute for Life Sciences, Jakarta, \\ 13210, Indonesia \\ ${ }^{2}$ Graduate School of Agriculture, Ehime University, Matsuyama, Ehime 790-8566, Japan \\ ${ }^{*}$ Corresponding author contact: agus.putra@i31.ac.id (A. B. N. Putra)
}

\begin{abstract}
Petis, one of Indonesia's traditional condiment, is most often made from shrimp and shrimp waste. This condiment becomes popular as a savory flavor additive which is mainly produced in East Java, Indonesia. Despite the unique taste and good nutritional content, any particular study regarding its health benefit in Indonesia has not thoroughly evaluated yet. Therefore, the objective of this research was to explore petis potential towards anti-allergy property in vitro. The potential property was evaluated by determining the concentration of Immunoglobulin E (IgE) by U266 cells treated with petis extract using ELISA. In result, petis extract could significantly suppressed IgE production up to 2-fold at its highest concentration compared to control. Further investigation to extrapolate petis functional bioactive compound was conducted by treating petis extract with heat and enzyme (proteinase K). Result showed that heat- and enzyme-treated petis extract still have the ability to suppress IgE production by U266 cells. Thus, it could be assumed that the functional bioactive compound was a heat-stable non-protein compound. These preliminary findings could conclude that petis extract has a potential anti-allergy property which gives an added value towards petis product in Indonesia.
\end{abstract}

Keywords: petis, IgE suppression, U266 cells, ELISA

\begin{abstract}
ABSTRAK
Petis merupakan salah satu kondimen tradisional Indonesia yang berbahan baku utama udang atau limbah udang. Kondimen ini terkenal sebagai penyedap rasa yang gurih dan banyak diproduksi di daerah Jawa Timur, Indonesia. Walaupun memiliki cita rasa yang khas dan kandungan gizi yang baik, sejauh ini belum ada kajian khusus mengenai khasiat petis untuk kesehatan di Indonesia. Oleh karena itu, eksperimen ini bertujuan untuk mengeksplorasi potensi anti-alergi ekstrak petis secara in vitro. Studi potensi tersebut dilakukan dengan mengevaluasi produksi Imunoglobulin E (IgE) oleh sel U266 menggunakan ELISA. Hasil penelitian menunjukkan bahwa ekstrak petis secara signifikan dapat menurunkan produksi IgE hingga 2 kali lipat pada konsentrasi tertinggi dibandingkan dengan kontrol. Untuk memprediksi senyawa bioaktif yang terkandung dalam ekstrak petis, maka dilakukanlah pengujian lanjut dengan memberikan perlakuan panas dan enzim (proteinase K) pada ekstrak petis. Hasil ELISA menunjukkan bahwa tetap terdapat tren penurunan produksi IgE oleh sel U266 meskipun ekstrak petis telah diberikan perlakuan panas dan proteinase K. Hal ini diperkirakan bahwa senyawa bioaktif tersebut merupakan komponen selain protein yang bersifat stabil pada suhu tinggi. Penemuan awal ini dapat menyimpulkan bahwa ekstrak petis memiliki potensi anti-alergi yang dapat diperkenalkan sebagai nilai tambah bagi produk petis di Indonesia.
\end{abstract}

Kata kunci: petis, penurunan produksi IgE, sel U266, ELISA 


\section{INTRODUCTION}

Petis, one of Indonesia's traditional condiment, is mainly produced from shrimp and its waste including shrimp skin, head, and tail. This condiment is popular with its unique characteristics: coal-black, sticky, pliant, and savory. The production of petis in Indonesia, especially in East Java, has been developed up to industrial scale (Huda, 2012). Commonly, the process of making petis starts with boiling the smashed shrimp waste along with the addition of sugar or palm sugar. After the solution is brought to boil, flavoring such as salt is added. Other than bringing a tasteful flavor to the petis, high salt content naturally acts as the preservative to the final product. Therefore, petis have a long shelf life (Jurusan Teknologi Pangan dan Gizi-IPB, n.d.).

The nutritional content in 100 gram of shrimp petis according to the data obtained from Daftar Komposisi Bahan Makanan (DKBM) (Depkes, 2016) is as follows: 220 kcal energy, 15 gr protein, 0.1 gr fat, 40 gr carbohydrate, $37 \mathrm{mg}$ calcium, $36 \mathrm{mg}$ phosphorus, and $3 \mathrm{mg}$ iron. Even though petis contains nutritious macro- and micronutrients, study regarding the effect of petis consumption towards health is rarely conducted. The latest evaluation found out the beneficial fibrolytic enzyme contained in petis which can be a therapeutic food for curing cardiovascular disease (Mine, Kwan Wong, \& Jiang, 2005). Other than that, the knowledge of petis has not explored yet in Indonesia. So, heretofore, the reason to consume petis is only based on its desired sensorial properties.

The objective of this study was to evaluate the effect of petis extract towards immune cells in vitro. By discovering novel health potential of petis, it is expected that the selling points and value of petis may increase. Thus, introducing petis as one of the valuable functional fermented food in Indonesia.
The cells used in this study were U266 cells which are a multiple myeloma secreting immunoglobulin $\mathrm{E}$ from peripherial blood (Sugahara, et al., 2009). Immunoglobulin E (IgE) is an antibody which induces type 1 hypersensitivity (Gould et al., 2003). The excessive signal for $\mathrm{IgE}$ secretion towards allergens can cause various allergic symptoms for type 1 hypersensitivity patients.

The evaluation of petis extract effect towards IgE production by U266 cells was conducted using enzyme-linked immunosorbent assay (ELISA). In addition, petis extract was further treated by heat and enzyme (Proteinase $\mathrm{k}$ ) in order to predict the functional bioactive compound in petis.

\section{METHODOLOGY}

\subsection{Sample preparation}

Commercially available petis (Petis Udang) was bought from the local supermarket in Jakarta area. It was dissolved in deionized water at $0.1 \mathrm{gr} \mathrm{mL}^{-1}$ and mixed for $24 \mathrm{~h}$ at $4^{\circ} \mathrm{C}$. The solution was then centrifuged $\left(12,000 \mathrm{rpm}, 20\right.$ minutes, $\left.4^{\circ} \mathrm{C}\right)$. The supernatant was collected and further centrifuged $\left(70,000 \mathrm{rpm}, 30\right.$ minutes, $\left.4^{\circ} \mathrm{C}\right)$. The supernatant was collected again and filtered through $3 \mu \mathrm{m}$ cellulose acetate membrane. The obtained filtrate was dialysed in a $500 \mathrm{Da}$ dialysis membrane for $48 \mathrm{~h}$ at $4^{\circ} \mathrm{C}$. The dialysed solution was collected and the $\mathrm{pH}$ was adjusted to 7.4. The final solution was sterilized by a $0.22 \mu \mathrm{m}$ filter, and collected into microtubes. All petis extract samples (PES) were stored at $-35^{\circ} \mathrm{C}$ prior to analysis.

\subsection{Sample treatments}

\subsubsection{Heat treatment}

Some prepared PES were heated at $100^{\circ} \mathrm{C}$ for 30 minutes. Then, they were cooled down to room temperature. Samples were centrifuged at $3,500 \mathrm{rpm}, 4^{\circ} \mathrm{C}$ for 10 minutes. The supernatant was collected into new 1.5 
$\mathrm{mL}$ microtubes and stored in $-35^{\circ} \mathrm{C}$ prior to analysis.

\subsubsection{Enzyme treatment}

Ten milligrams of Proteinase $\mathrm{K}$ was diluted with $2 \mathrm{~mL}$ of deionized water and mixed for 15 minutes. The solution was filtered using a $0.45 \mu \mathrm{m}$ filter aseptically. Proteinase $\mathrm{K}$ solution was added to some prepared PES at $100 \mu \mathrm{L}$ each. The samples were incubated at $37^{\circ} \mathrm{C}$ for 20 hours. Proteinase $\mathrm{K}$ activity was deactivated by heating at $100^{\circ} \mathrm{C}$ for 5 minutes. Samples were centrifuged at $3,500 \mathrm{rpm}, 4^{\circ} \mathrm{C}$ for 10 minutes. The supernatant was collected into new 1.5 $\mathrm{mL}$ microtubes and stored in $-35^{\circ} \mathrm{C}$ prior to analysis.

\subsection{Total protein quantification}

Protein standard BSA (bovine serum albumin) solutions were prepared at the following concentrations adjusted with phosphate buffered saline (PBS): 0, 200, 400, $600,800,1000,1200,1400,1600,1800$, and $2000 \mu \mathrm{g} \mathrm{mL} \mathrm{mL}^{-1}$. Five microliters of each sample and standard solution was transferred into their respective wells in a 96-microwells plate. Then, $25 \mu \mathrm{L}$ of Reagent A (BIORAD) was added to each wells, followed with the addition of $200 \mu \mathrm{L}$ Reagent B (BIORAD) away from light. The plate was shaked with a mixer for 15 minutes. The absorbance of sample was read using plate reader with the setting as follows: measure $=655 \mathrm{~nm}$ and reference $=415 \mathrm{~nm}$.

\subsection{ELISA}

2.4.1 U266 cell culture

PES were diluted to several concentrations: 75,300 , and $675 \mu \mathrm{g} \mathrm{mL} \mathrm{m}^{-1}$. Then, $50 \mu \mathrm{L}$ of each sample was transferred to each respective well in a 96-microwells plate. Ten millimolars of NaPB was used as the control. Medium solution for U266 cells consists of $10 \mathrm{~mL}$ sterilized water, $100 \mu \mathrm{L}$ Insulin (Sigma), $100 \mu \mathrm{L}$ Transferrin (Sigma),
$100 \mu \mathrm{L}$ Ethanolamine (Sigma), and $100 \mu \mathrm{L}$ Sodium Selenite (Sigma). Fifty microliters of medium solution was transferred into each respective wells in a 96-microwells plate. Then, U266 cells maintained in a $1 \times$ RPMI1640 medium were seeded into a 96-well culture plate (Corning) at $0.5 \times 10^{4}$ cells well $^{-1}$. The sample and cells were incubated at $37^{\circ} \mathrm{C}$ with $5 \% \mathrm{CO}_{2}$ for 20 hours before conducting ELISA assay.

\subsubsection{IgE ELISA}

Coating: $100 \mu \mathrm{L}$ of $1000 \times$ diluted antihuman IgE antibody in a $50 \mathrm{mM}$ carbonate buffer $(\mathrm{pH}$ 9.6) was transferred into each respective wells in a 96-microwells plate. The plate was incubated at $37^{\circ} \mathrm{C}$ for 2 hours. Blocking: the plate was washed three times with Tween20-phosphate buffered saline (TPBS). Then each wells was filled with $300 \mu \mathrm{L}$ $5 \%$ skimmed milk-PBS solution. The plate was incubated at $37^{\circ} \mathrm{C}$ for another 2 hours. Sampling: 5\% skimmed milk-PBS and 100 $\mathrm{ng} \mathrm{mL}^{-1}$ IgE standard solution was prepared at the following concentrations: $0,5,10,15$, $20,25,30,35,40,50,60,70$, and $100 \mathrm{ng}$ $\mathrm{mL}^{-1}$. The incubated plate was washed three times with T-PBS. Then each respective wells was filled with $50 \mu \mathrm{L}$ standard solution or the supernatant of cultured U266 cells. The plate was incubated at $37^{\circ} \mathrm{C}$ for 1 hour. $2^{\text {nd }}$ Antibody: the plate was washed three times with T-PBS. Then each wells was filled with $100 \mu \mathrm{L}$ anti-human $\operatorname{IgE} 2^{\text {nd }}$ antibody (Biosource International AHI0604) which has been $20000 \times$ diluted with 5\% skimmed milkPBS. The plate was incubated at $37^{\circ} \mathrm{C}$ for another 1 hour. Avidine-Biotin Complex: the plate was washed three times with T-PBS. One hundred microliters of conjugated strepavidin-horseradish peroxidase (diluted $4000 \times$ with $1 \%$ BSA-PBS) was added to each respective well. The plate was incubated at $37^{\circ} \mathrm{C}$ for 1 hour. Coloring: the plate was washed three times with T-PBS. A coloring solution consists of citrate buffer $(\mathrm{pH} \mathrm{4.0)}$, 
deionized water, and $0.06 \mathrm{mg} \mathrm{mL}^{-1}$ ABTS with the ratio of 10:9:1 was prepared. One hundred microliters of the coloring reagent was transferred into each respective well. The plate was let to sit for 10 minutes away from light. One hundred microliters of stop solution consisting of $1.5 \%$ oxalate acid was added to each well. The sample absorbance was read using plate reader with the setting as follows: measure $=415 \mathrm{~nm}$ and reference $=$ $655 \mathrm{~nm}$.

\subsection{Real-time RT-PCR}

U266 cells suspended in ITES-RPMI1640 medium $(1.25 \mathrm{~mL})$ containing PES at $675 \mu \mathrm{g} \mathrm{mL}^{-1}(1.25 \mathrm{~mL})$ were seeded into a 60 $\times 15 \mathrm{~mm}$ culture dish at $5 \times 10^{5}$ cells dish $^{-1}$. After incubation for $24 \mathrm{~h}$ at $37^{\circ} \mathrm{C}$, cells were harvested and RNA was isolated using Sepasol-RNA I Super G (Nacalai Tesque) according to the manufacturer's instruction to obtain cDNA template using MMLV-reverse transcriptase (Promega, Madison, WI, USA) and oligo-(dT) $)_{20}$ (Toyobo).

Table 1. Primer sequences

\begin{tabular}{ll}
\hline Genes & Sequences \\
Human & 5'-ATGACCTTACCAGCCACC \\
IgE & AC-3' (sense) \\
& 5'-GGTTTTGTTGTCGACCCA \\
& GT-3' (anti-sense) \\
\hline Human & 5'-TCCATGACAACTTTGGCATCGT \\
GAPDH & GG-3' (sense) \\
& 5'-GTTGCTGTTGAAGTCACAGGAG \\
& AC-3' (anti-sense) \\
\hline
\end{tabular}

Real Time RT-PCR samples consisting of $2 \mu \mathrm{L}$ of cDNA sample, $10 \mu \mathrm{L}$ of SYBR Green PCR Master Mix, $1 \mu \mathrm{L}$ each of $10 \mu \mathrm{M}$ forward and reverse primer were prepared in microtubes. Thermal cycling conditions were prepared with the following settings: $95^{\circ} \mathrm{C}$ for 20 seconds, 40 cycles of $95^{\circ} \mathrm{C}$ for 3 seconds, and $60^{\circ} \mathrm{C}$ for 30 seconds. The relative gene expression was calculated based on the comparative CT method and normalized by measuring in parallel approach to the expression of glyceraldehyde 3-phosphate dehydrogenase (GAPDH) gene. Primer sequences used in this experiment are shown in Table 1.

\subsection{Statistical calculation}

Data obtained were expressed as mean \pm standard deviation (SD). One-way ANOVA followed by student's t-test was used to assess the statistical significance of the difference against control. Values with $* p<$ 0.05 , ** $p<0.01$, or $* * * p<0.001$ were considered statistically significant.

\section{RESULTS AND DISCUSSION}

\subsection{IgE Suppression and Mechanism}

$\mathrm{IgE}$ is produced and secreted by the plasma cells after an invading allergen was detected. IgE will attach to the surface of mastocyte; thus, sending signals to secrete histamine and cytokines. People who suffer from type I hypersensitivity overproduce IgE towards the detected allergen. Therefore, the secretion of histamine and cytokines become excessive in blood and result in allergic reaction which symptoms may vary for every patients (Gould, et al., 2003).

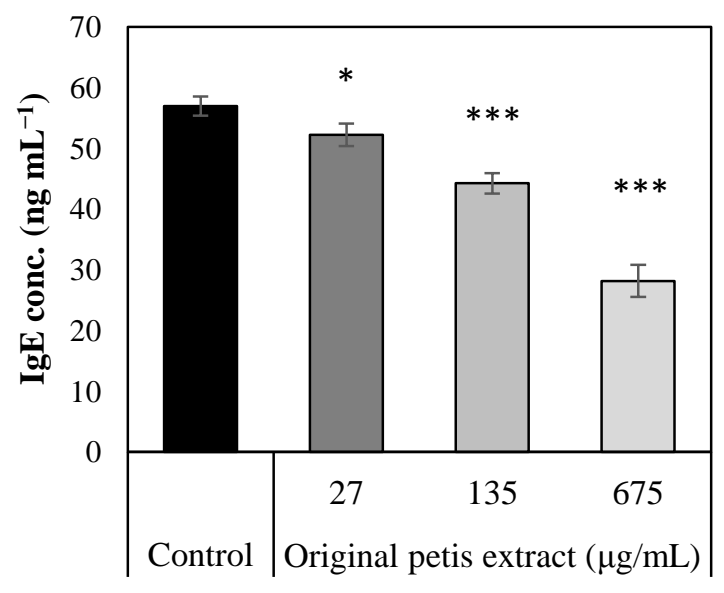

Figure 1. Effect of petis extract on IgE production by U266 cells. Results are shown as mean \pm standard deviation of two 
independent measurements. Statistically significant differences against control are represented as $* p<0.05$ or $* * * p<0.001$.

According to IgE ELISA result shown in Figure 1, it was found that petis extract could significantly suppressed the production of IgE by U266 cells at increasing concentration. The suppression of IgE production reached up to 2-folds at the highest concentration compared to that of the control.

Correlating this finding to the existing molecular pathway, the suppression of IgE production may decrease the secretion signal for histamine and cytokines. Therefore, the allergic symptoms for type 1 hypersensitive patients can be reduced. This result proposed a novel potential of petis extract in having an anti-allergy property.

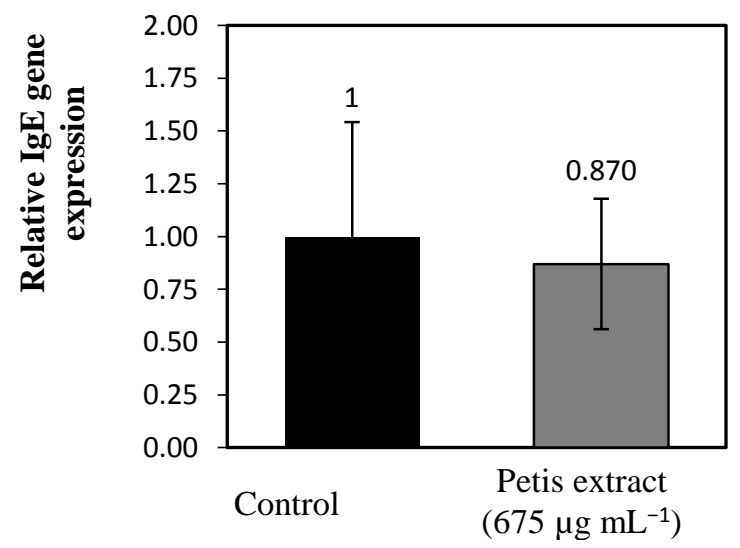

Figure 2. Effect of petis extract on IgE gene expression by U266 cells. Results are shown

as mean \pm standard deviation of two independent measurements.

Subsequently, real time RT-PCR was conducted to further extrapolate the possible IgE suppressing mechanism of petis extract. As shown in Figure 2, IgE relative gene expression level between control (1.00) and petis extract-treated U266 cells (0.87) were not significantly different. This result found that IgE suppressing mechanism of petis extract was not through lowering $\operatorname{IgE}$ gene expression level of the cells. Further analysis in translational, post-translational, and/or other protein turnover mechanisms should be conducted to determine the other possible IgE suppressing mechanisms of petis extract (Welle, 1999).

\subsection{Initial extrapolation of IgE suppressing bioactive compound}

The bioactive compound in petis was extrapolated by giving some treatments towards petis extract: heat and enzyme treatments. Heat treatment was used to denature all heat labile compounds contained in petis extract prior to ELISA, leaving only heat stabile compounds functioning. The purpose of adding Proteinase $\mathrm{K}$ in enzyme treatment was to break the peptides bonds within the sample. Therefore, proteins were denatured prior to ELISA.

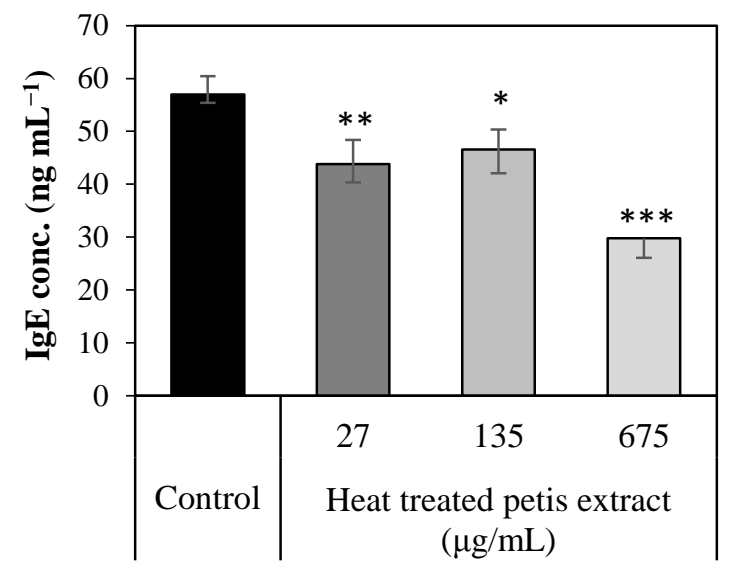

Figure 3. Effect of heat-treated petis extract on IgE production by U266 cells. Results are shown as mean \pm standard deviation of two independent measurements. Statistically significant differences against control are represented as $* p<0.05, * * p<0.01$, or $* * *$

$$
p<0.001 \text {. }
$$

Heat-treated petis extract still showed a lowering $\operatorname{IgE}$ production effect compared to that of the control (Figure 3). Moreover, enzyme-treated petis extract (Figure 4) also showed the same suppressing trend as the untreated petis extract (Figure 1) despite the distinctive significant difference value. The 
results from heat and enzyme treatment proposed that the properties of the bioactive compound contained in petis extract was heat stable and assumed to be a non-protein compound.

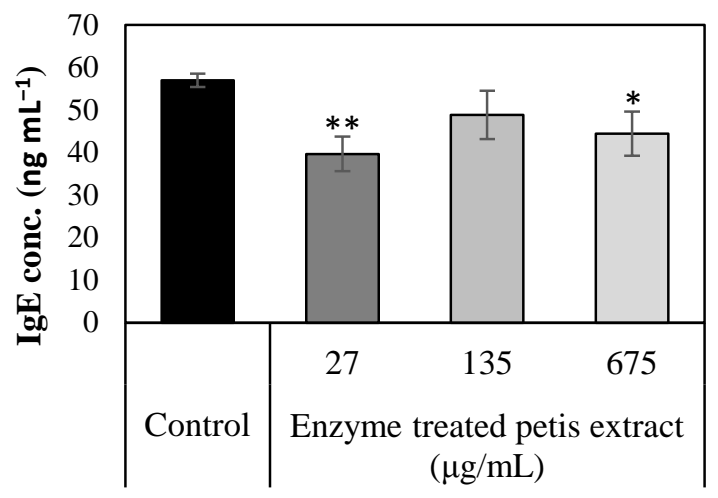

Figure 4. Effect of enzyme-treated petis extract on IgE production by U266 cells. Asterics annotating level of significant difference compared to control $(* p<0.05$ and $* * p<0.01)$.

\section{CONCLUSION}

Petis extract performed a novel potential of anti-allergy property through its significant suppression of IgE production in vitro compared to that of the control sample. Its mechanism, however, was not occurred through alteration of $\operatorname{IgE}$ gene expression level, but rather through other possible mechanisms that should be further researched. Result from heat and enzyme treated petis extract assumed that the functional bioactive compound contained in petis extract was a heat-stable non-protein compound. The findings of this study could contribute as preliminary data in developing IgE supressing functional food for type I hypersensitive patients.

\section{ACKNOWLEDGEMENT}

Authors would express gratitude to all member of the Laboratory of Animal Cell Technology, Ehime University, Japan.

\section{REFERENCES}

Alberts, B., et al. (2014). The Innate and Adaptive Immune Systems. Molecular Biology of the Cell, $6^{\text {th }}$ Ed. New York: Garland Science.

Butler, M. (2004). Growth and Maintenance of Cells in Culture. Animal Cell Culture and Technology. BIOS Scientific Publisher.

Huda, N. (2012). Indonesian fermented fish products, Handbook of Animal-Based Fermented Food and Beverage Technology $2^{\text {nd }}$ Ed., Hui, Y. H. (Ed.). New York: CRC Press Taylor \& Francis Group.

Jurusan Teknologi Pangan dan Gizi-IPB. No date. Pembuatan Terasi dan Petis. Tekno Pangan \& Agroindustri, Volume 1 No. 3. Retrieved 29 January 2017 from http: /warintek.ristekdikti.go.id/pangan_kesehat an/pangan/ipb/Terasi\%20dan\%20petis.pdf.

Gould, H.J., et al. 2003. The biology of IgE and the basis of allergic disease. Annu. Rev. Immunol. 21: 579-628. Doi:10. 1146/annurev.immunol.21.120601.141103. Mine, Y., Kwan Wong, A. H., \& Jiang, B. (2005). Fibrinolytic enzymes in Asian traditional fermented foods. Food Research International, 38(3), 243-250.

Racine, R., McLaughin M., Jones DD., et al. (2011). IgM production by bone marrow plasmablasts contributes to long-term protection againts intracellular bacterial infection. J. Immunol. 186(2): 1001-21.

Sugahara, T., Nishimoto, S., Morioka, Y., Nakano, K., \& Nakano, K. (2009). White sorghum (Sorghum bicolor (L.) Moench) bran extracts suppressed IgE production by U266 cells. Bioscience, Biotechnology, and Biochemistry, 73(9), 2043-2047.

Welle, S. (1999). Human Protein Metabolism. New York: Spinger-Verlag New York Inc. 